\title{
The Perspective of Food Sustainability and Security for Forest Edge Community through Increasing Coffee Competitiveness for Income Sustainability
}

\author{
Toni Herlambang ${ }^{1}$, Noor Salim ${ }^{2}$, Oktarina $^{3}$ \\ ${ }^{1}$ Economic Faculty, Muhammadiyah University of Jember \\ ${ }^{2}$ Engineering Faculty, Muhammadiyah University of Jember \\ ${ }^{3}$ Agronomy Faculty, Muhammadiyah University of Jember \\ email: toniherlambang@unmuhjember.ac.id
}

\begin{abstract}
The consumption of rice on the edge of the forest tends to increase unbalanced with production causing food insecurity. Efforts to strengthen the food security of forest-edge communities can be through diversification of non-rice food (corn, sweet potato, banana, cassava and arrowroot) and increased income of smallholder coffee farmers. The objectives of the research are to obtain a model of increasing the competitiveness of the people's coffee to strengthen the resilience and security of forest-edge communities. Research location in Bondowoso District. The results of the research show that: (1) The model of enhancing the competitiveness of coffee people can strengthen the resilience and security of marginalized communities by involving local institutions in Jember (Perhutani, Plantation Department, Industry Office, Coffee and Cocoa Research Center, Cooperative Service, and Higher Education). (2) The strategy to strengthen the resilience and security of the food of marginalized forest communities can also through the diversification of non-rice food consumption. (3) Diversification of non-rice food consumption (66-77\%) and rice (23-34\%). (4) In general, the food security and security of forest-edge communities in the category is quite steady.
\end{abstract}

Keywords: food sustainability; coffee competitiveness; edge community

\section{Introduction}

Food diversification as an effort to strengthen or cultivate a pattern of consumption of foods that are diverse and balanced and safe in sufficient quantities and composition that will meet nutritional needs and support healthy, active and productive life[1] in strengthening food security in Indonesia in Presidential Regulation No. 22 (2009) and the East Java Regional Government Policy (2010) include: (1) dependence on rice consumption is still quite high and the utilization of local food is not optimal for daily food consumption, (2) government food reserves are still limited (only rice and managed by the government central), while local government reserves and forest marginal communities have not yet developed, (3) undeveloped local food-based food technology to support diversification of food 
consumption[2]. The failure of the development of food security and security on the edge of forestry forestry has been caused by a lack of participatory community involvement in it.

People tend to be prohibited from using the forest without any solution, while those who live around the forest area must meet their daily needs. As a result, disruption to forest resources is difficult to avoid. Some programs such as conservation of protected forests with the community, have succeeded in bringing forest managers closer to the surrounding community and increasing the income of forest communities. However, the program has not been able to significantly improve food security and income of forest communities, namely the existence of conflicts of interest between the institutions involved (stakeholders) and the existence of lost local product-based employment opportunities [3]

For this reason, this issue needs to be resolved immediately, one of them is by building a model for increasing the competitiveness of the people's coffee to strengthen the resilience and security of the forest edge community. This model has the advantage of increasing the diversification of food and income of communities around the forest, reducing conflicts between institutions and increasing employment opportunities based on local products. So that in general the impact of food security and security and increasing the rate of forest rehabilitation will be significant.

The aim of the research is to obtain a model to increase the competitiveness of the people's coffee to strengthen the resilience and security of the forest edge community.

\section{Methodology}

The approach used in this study is a participatory approach both in order to obtain qualitative and quantitative data to provide a more complete explanation of the scope of the discussion of the issues under study. The participatory (qualitative) approach is directed to be more grounded for an interesting case study which is revealed as supporting the diversification model of food consumption which is the output of research.

Considering the type of research activity being applied, the PRA (Participatory Rural Appraisal) method is used from the first year to the second stage. The PRA method in this study principled on "playing an equal role and doing together" between researchers and respondents, so the technique will be carried out in a way: researchers are in the middle of the respondent's life and are part of their lives. Besides that, considering the formulation of the objectives to be achieved oriented towards changes in the behavior patterns of the people on the outskirts of the forest certainly requires a short time. A gradual process was carried out in a planned manner starting to increase awareness, delivering information on educational material, training and mentoring to monitoring and evaluation. This research was conducted from January to December 2018

Research locations in Sumber Wringin, Tamanan, Wringin and Sukosari Districts, Bondowoso Regency. Determination of the sample is stratified random sampling. Data is collected through PRA, FGD, RRAS, indept interview and survey methods.

Food sustain and security at the Bondowoso Regency research location is calculated using the Aggregate formula. Household Food Security Index (AHFSI) proposed by Sen [4] and Bigman [5] is as follows.

$$
A H F S I=100-[H\{G+H(1-G) I\}+0.5 Q\{1-H\{G+(1-g) I\}] 100
$$


Where :

$\boldsymbol{H}=$ head-count ratio, the proportion of people who lack food (calories or protein). The $\mathrm{H}$ value ranges between 0 and 1, indicating a small proportion of households that are still below the minimum food sufficiency limit.

$\boldsymbol{G}=$ food gap, the proportion of the shortage of food sufficiency is minimal. The G value ranges between 0 and 1 , reflecting the low rate of deficiency in food for households that are still below the food adequacy limit.

$\boldsymbol{I}=$ the level of inequality (gini ratio) of the food gap distribution. The value of I ranges between 0 and 1, illustrating the level of inequality in the distribution of food deficiencies. $Q=$ coefficient of variation from the realization of food consumption. Q values range between 0 and 1, indicating the low risk of a household being included in the food shortage category.

\section{Discussion}

\subsection{Diversification of Non Rice Food Consumption}

Diversification of food consumption for forest margins in 4 research locations in Kabupaten Bondowoso shows that in the last 1 year the amount and type of food consumed by households is as follows:

1. Sumber Wringin District: Rice (23\%): Non rice (77\%), including: corn, sweet potato, cassava, taro, suweg, gadung, spinach, bean sprouts, mustard greens, eggplant, long beans, lettuce, cabbage, fern, heart of banana, koro, kecipir, cassava leaves, papaya leaves, banana, ice, tea, and coffee.

2. Tamanan District: rice (34\%) and non rice (66\%), including: corn, cassava, taro, instant noodles, potatoes, arrowroot, gadung, spinach, Moringa, mustard greens, green beans, eggplant, long beans, young jackfruit, soup, gambas, cabbage, fern, kale, young papaya, cassava leaves, bananas, watermelon, sapodilla, starfruit, oranges, melon, klengkeng, jackfruit, apples, tea, coffee, compote, milk.

3. Wringin District: Rice (33\%) and Non rice (67\%), including: corn, sweet potato, cassava, taro, potato, suweg, canna, gadung, garut, spinach, mustard greens, eggplant, long beans, jackfruit young, soups, radishes, lettuce, cabbage, carrots, cucumber, cassava leaves, broccoli, bananas, watermelon, papaya, salak, apple, jackfruit, coffee, tea, ice, sugar water, milk.

4. Sukosari District: Non rice (69\%), rice (31\%) include: corn, sweet potato, cassava, taro, instant noodles, potatoes, spinach, bean sprouts, eggplant, candied, lamtoro, cauliflower, tamarind, long beans, jackfruit, soups, radishes, lettuce, cabbage, ferns, carrots, kale, tea, coffee, ice, milk, sugar water, bananas, watermelon, klengkeng, cantaloupe.

\subsection{Household Food Security Index (AHFSI)}

Household-level Food Consumption Resilience Index in 4 research locations in

Bondowoso District for each household shows that:

a. AHFSI SumberWringin District $=100-[\mathrm{H}\{\mathrm{G}+\mathrm{H}(1-\mathrm{G}) \mathrm{I}\}+0.5 \mathrm{Q}\{1-\mathrm{H}\{\mathrm{G}+(1-$ g) I $\}] 100=100-[0.55\{0,45+0,55(1-0,45) 0,25\}+0,50,33\{1-0,55\{0,45+(1-$ $0,45) 0,25\}] 100=100-24.75=75.25$. This means that food security is quite stable. 
b. AHFSI in Tamanan District $=100-[\mathrm{H}\{\mathrm{G}+\mathrm{H}(1-\mathrm{G}) \mathrm{I}\}+0.5 \mathrm{Q}\{1-\mathrm{H}\{\mathrm{G}+(1-\mathrm{g})$ I\}] $100=100-[0,5516\{0,4484+0.5516(1-0.4484) 0.25\}+0.55160 .33\{1-$ $0.5516\{0.4484+(1-0.4484) 0.25\}] 100=100-[0,2893+0,6766] 100=100-23,54$ $=76,46$. This means that food security is quite stable.

c. $\boldsymbol{A H F S I}$ Wringin District $=100-[\mathrm{H}\{\mathrm{G}+\mathrm{H}(1-\mathrm{G}) \mathrm{I}\}+0.5 \mathrm{Q}\{1-\mathrm{H}\{\mathrm{G}+(1-\mathrm{g}) \mathrm{I}\}]$ $100=100-[0,5108\{0,4484+0,5108(1-0,4892) 0,25\}+0,55160,33\{1-0,5108$ $\{0,4892+(1-0,4892) 0,25\}] 100=100-18.69=81.31$. This means that food security is very stable.

d. AHFSI Sukosari District $=100-[\mathrm{H}\{\mathrm{G}+\mathrm{H}(1-\mathrm{G}) \mathrm{I}\}+0.5 \mathrm{Q}\{1-\mathrm{H}\{\mathrm{G}+(1-\mathrm{g}) \mathrm{I}\}]$ $100=100-[0,2973\}+0,1218\}] 100=100-21.91=78.09$. This means that food security is quite stable.

\subsection{The Model}

Based on the results of Focus group discussions, conducted on the respondents of smallholder coffee farmers on the edge of the forest in four sub-districts in Bondowoso district, in order to increase the competitiveness of the people's coffee, with the results presented in the model as follows (see the picture).

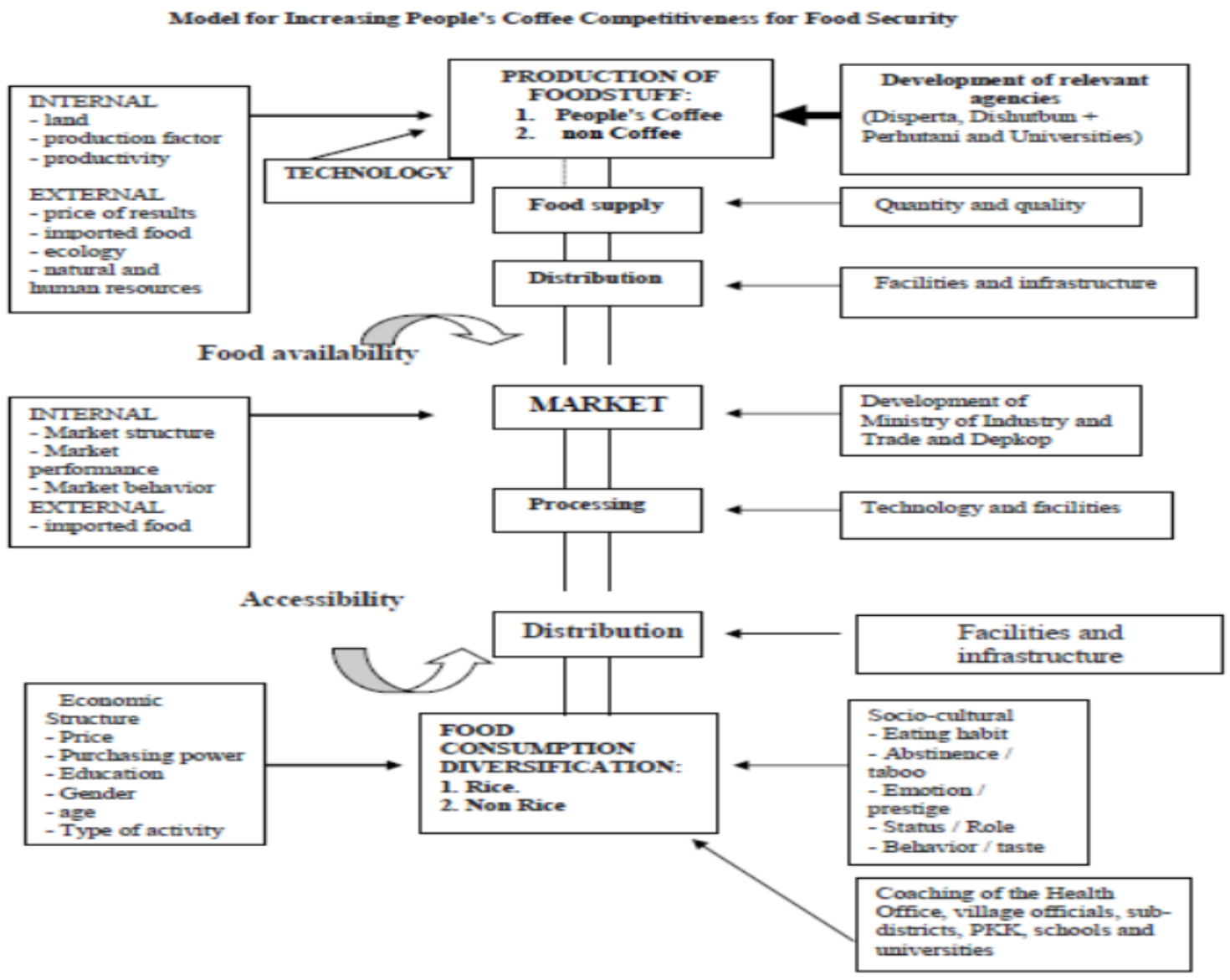


Based on the model, first, it can be explained that there is a link between coffee products and other food products (Non-coffee), meaning that the development and competitiveness of coffee products depend on how much food security the coffee-producing people. technically decreasing food security can reduce coffee competitiveness. Second, the model explains that efforts to increase coffee competitiveness must be supported by the collaboration of many parties, both government and non-governmental organizations. Thirdly, forest peripheral communities desperately need technical guidance in developing their food products; on average they do not know the latest mechanisms for agribusiness and agrotechnology, even most are still blind in business management. Fourth, this is the most important, until now the land they use is not their property, but it still belongs to companies in the plantation and forest product companies (PTP / BUMD / Perhutani), so they are not calm and lack focus in developing their food products, they are worried that the land used will be taken by the owner. Fifth, they only make food business as a side job (because the land is not theirs), their main jobs are company workers, masons, and other informal sectors, so that there needs to be a comprehensive solution from the government and related institutions for improvement food security and coffee competitiveness can be realized, essepecially for forest edge community.

\section{Conclusion}

1. The model for increasing the competitiveness of the people's coffee can strengthen the resilience and security of the forest periphery by involving local institutions in Bondowoso (Perhutani, Plantation Service, Industry Office, Coffee and Cocoa Research Center, Cooperative Service, and Universities). In general, the resilience and food security of forest people in the category is quite steady.

2. Diversification of non-rice food consumption (66-77\%) and rice (23-34\%) food security in the periphery of the forest can also be through diversification of non-rice food consumption.

3. In general, community food security on the edge of the forest in the category is quite steady. If the land used is not revoked by the owner

4. There is a link between coffee products and other food products (Non-coffee), meaning that the development and competitiveness of coffee products depend on how much food security the coffee-producing people. technically decreasing food security can reduce coffee competitiveness

\section{Acknowledgments}

We would like to thank the Higher Education Council for funding this research, as well as the participation of respondents and related parties 


\section{References}

J. Salem and, M. Mojaverian, Study of relationship between food security, urban population and development plans in Iran, Environmental Resources Research Vol. 5, No. 2, 2017

BKPRIAU. 2010. Kerangka Pikir Pemantapan Ketahanan Pangan. Badan Ketahanan Pangan Riau. Http//www.bkpriau.go.id.

BPS, 2010. Jawa Timur dalam Angka. Kerjasama Badan Perencana Pembangunan Kabupaten Jember dengan BPS Kabupaten Jember.

Food and Agriculture Organization of the United Nations, 2001. Some Issues Relating to Food Security in the Context of WTO Negotiations on Agriculture",Geneva Round Table on Food Insecurity in the Context of WTO Negotiations on Agriculture 2001. Discussion Paper No. 1, Rome, Italy: FAO.

Sen, A.K. 1976. Poverty: An ordinal approach to measurement. Econometrical. 44, 219-231.

Bigman, D. 1993. The measurement of food security. In: Berck, P. / Bigman, D (eds.1993): Food security And Food Inventories. In Developing Countries. Wallingford: CAB International. 238-251 